\title{
MINDFULNESS TRAINING TO REDUCE EXAM ANXIETY IN ELEMENTARY STUDENTS
}

\author{
Joice Kartika Sari ${ }^{1}$ \\ ${ }^{1}$ Pelangi Hati Child Development Center \\ J1. Jangli Gabeng Raya No. 1, Semarang, Central Java (Indonesia) \\ ORCID ID: https://orcid.org/0000-0003-1518-8053
}

UDC: 159.99

\begin{abstract}
Nowadays, anxiety problem is facing not merely by adults. Children are also faced with situations when anxiety appears. As for students, exams are considered as one of such situations that cause anxiety. Regarding to the problem, this research focuses on anxiety experienced by students from the fourth and fifth grade of elementary school. The mindfulness training was used with the purpose to know how helpful this approach for controlling over anxiety experienced by the students from the fourth and fifth grade of elementary school. This study showed that the mindfulness training can reduce the level of exam anxiety in the experimental group better in comparison with the control group. It is seen through the paired t-test results with the significance level of 0.000 , which is smaller than the significance standard of 0.05 . The independent t-test for the pre-test results obtained at the experimental and control groups showed the significant levels of 0.488 and 0.482 , which bigger than the significance standard. Hence, the mindfulness training can be used as an alternative way, in which someone's attention is pulled to the present moment to break the maladaptive anxiety chain.
\end{abstract}

\section{Introduction}

Keywords: anxiety, children's anxiety, exam's pressure, mindfulness training.

ments from society are experienced by many people, not only by children (Waring, 2014).

In this modern era, children are faced by Karr and Johnson (as qtd. in Nijboer, 2007) menmany situations which cause stress. Such pres- tion that children in elementary school identify sures and expectations to have good achieve- school as a place full of pressure and stress com-

Address for correspondence, e-mail: editpsychas@gmail.com Copyright: (C) Joice Kartika Sari

This is an Open Access journal, all articles are distributed under the terms of the Creative Commons AttributionNonCommercial-ShareAlike 4.0 International (CC BY-NC-SA 4.0) License (http://creativecommons.org/licenses/by-nc$\mathrm{sa} / 4.0 /$ ), allowing third parties to copy and redistribute the material in any medium or format and to remix, transform, and build upon the material, provided the original work is properly cited and states its license. 
pared to other places. Several studies found that young children have anxiety mostly related to the academic field (Ergene, 2011; Nyroos, 2014; Talbot, 2016; Waring, 2014).

The researcher has obtained reports from students' parents and teachers about fears that face their children. Some of the students have, for example, nausea and dizziness in the morning of that day, when they have exams. In addition, they also lose appetite, become moody, more emotional and aggressive.

In addition, the students tend to daydreaming while doing an exam, frequently ask permission to go to bathroom, and even some students experience nausea before presentation or an exam.

Furthermore, there also students in the fifth form of elementary school who always have cold sweats and some of them are frequently asking to the teacher whether or not the questions for an exam are difficult. The children are worry to got bad scores and be mocked by their friends.

Based on the discussion and dialogue with the teachers of the fourth and fifth forms, the information obtained is that there is also the tendency of the students to react: "Aaaaa.... Why it should be an exam again? It's so difficult!" when a teacher announce about a topical test or an exam.

The researcher personally listened to the fifth-form students who said that they would be happier if they did not have to pass exams or tests, because exams are difficult and make them feel anxious if they get bad scores. Some of the students also convey that exam should not be limited by time, thus they can think clearly. So, we can say that the fourth-forth-form students often experience the symptoms of exam anxiety.

The 10-12 years old children, who study generally in the $4^{\text {th }}-6^{\text {th }}$ forms of elementary school, are entering to the late childhood period. Eccles and Roeser (as qtd. in Schonert-Reichl et al., 2015) argues that the late childhood is the time of transition to puberty where behavior and emotional problems frequently appears during this age period.

Yusuf (2004) states that at this period, children realize that harsh emotion disclo- sure are not accepted by teachers, friends, or even parents. Therefore, children begin to control emo- tional expressions of their anxiety. It is in line with their efforts to control their emotions that are manifested in daydreaming, decreased concentration in class, verbal comments, or physiology symptoms.

One of the factors, causing psychological interferences, is a mindset and irrational believes of an individual (Bridges \& Harnish, 2010). According to Furr et al. (as qtd. in Gerwinget al., 2015), an individual, having exam anxiety, usually fears failures. There are several studies which show that anxiety is the more often cause of failure at exams then psychological pressure (Segool et al., 2014).

If the anxiety experienced by the students in this period is not overcome properly, it will 
cause negative impacts. The anxiety problems facing by the students are mostly caused by huge amount of learning material, longer study hours, high competency expected from the students at this stage. This condition is also considered as one of mental health problems, which experienced by children mostly in the late childhood during transition to the adolescence and puberty period.

As mentioned by Schonert-Reichl et al., (2015), effective coping strategies taught and provided at the late childhood can support selfregulation and self-reflection. Hence, it can decrease or even prevent mental health problems in the academic field. The mastered positive problem-overcoming strategies for anxiety can help also form positive emotions, so children can be more concentrated on their learning (Yusuf, 2004).

One of the approaches, widely used to increase the students' well-being in school, is the mindfulness exercises (Huppert \& Johnson, 2010). The Mindfulness meditation has become integral element of the Positive Psychology, and its implementation is rapidly developed in the psychological therapy (Albrecht, et al., 2012).

Mindfulness is not a merely technique since it also contains a set of values which is in line with Positive Psychology (Cebollaet al., 2017). This approach is one of strategies used broadly and it is obtained positive acceptance in the educational field to help improve an individual's well-being (Albrecht et al., 2012). Furthermore, Rempel, (2012) has found some empirical evidences that Mindfulness potentially can help children with anxiety problem.

Thus, based on the explanation above, this research will focus on the anxiety problem experienced by students on the fourth and fifth grade of elementary school. This research also uses the mindfulness training to know how helpful this approach for controlling of anxiety experienced by the students on the fourth and fifth forms of elementary school.

\section{Research Method}

This research uses the experimental technique with the pre-test and post-test control group design. The variables involved in this research are: one independent variable and one dependent variable. The independent variable is the mindfulness training and the dependent variable is exam anxiety.

This research involved 28 elementary school students, 15 of them were from the fourth grade and 13 students were from the fifth grade. The students had average to high exam anxiety. The division of students between the experiment and control groups was performed randomly.

To collect research data, the Exam Anxiety Scale developed by the researcher was used in the form of self-report. The report form was based on the component theory proposed by Wren \& Benson (2004). The Exam Anxiety Scale consist of 25 questions that must be filled by the researched subjects with "Yes" or "No" answers in accordance with the subjects' feeling (Table 1). 
Table 1. The Distribution of Anxiety Scale Items (Before Validity Test Conducted)

\begin{tabular}{l|l|c}
\hline \multicolumn{1}{c|}{ Component } & \multicolumn{1}{c|}{ Items number } & Amounts \\
\hline Thoughts & $1,4,6,9,10,11,16,20,22$ & 9 items \\
\hline Off -Task Behaviors & $3,7,13,15,17,18,23,24$ & 8 items \\
\hline Autonomic Responses & $2,5,8,12,14,19,21,25$ & 8 items \\
\hline \multicolumn{2}{c}{ Total Items } & $\mathbf{2 5}$ items \\
\hline
\end{tabular}

The Mindfulness Training Module was used as training materials in this research. This module was developed by the researcher and contains mindfulness training techniques for children with reference to the mindfulness training model applied by Napoliet al., (2005). According to Napoli et al., (2005) the proposed exercises decrease effectively the exam anxiety. The training duration and the proposed exercises are described in the table 2 below (Table 2): $r$ table for degree of freedom $(\mathrm{df})=\mathrm{n}-2$ with alpha 0.05 . If the value of $r$ count is greater than $r$ table and the value of $r$ count is positive, hence the Scale is valid. The validity test used in this research is Pearson product moment.

\section{2) Reliability}

The reliability was tested in this research with Cronbach Alpha technique. The measurement Scale said is reliable if Cronbach's alpha greater than 0.60 . Otherwise, if the value of Corn-

Table 2. The Training Duration and Mindfulness Exercises

\begin{tabular}{l|c}
\hline \multicolumn{1}{c|}{ Exercises } & $\begin{array}{c}\text { Duration } \\
\text { (minutes) }\end{array}$ \\
\hline Mindfulness Smile & 9 \\
\hline Breathing & 3 \\
\hline Physical Activities & 9 \\
\hline Sensory Activities & 9 \\
\hline \multicolumn{1}{c}{ Total duration per session } & 30 \\
\hline
\end{tabular}

As for validity and reliability of the measurement Scale, we can define the following:

1) Validity

The validity in this research was the level of appropriateness between limitations conceptual given by the help of operational developed. It is performed by comparing the value of $r$ count and bach's Alpha is less than 0.60 , then the measurement Scale is not reliable. The greater the value of Cronbach's Alpha is, the higher reliability of the Scale is.

The research procedure can be described as follow: 
DOI (Issue): https://doi.org/10.31108/1.2019.5.11

\section{1) The sample and subject choosing}

The sample of this research consisted of 15 fourth-grade students and 13 fifth-grade students. The division of the students between the experiment and control groups was performed randomly. The subjects for this research were chosen based on the pre-test given to all fourth and fifth-grade students of elementary school. Based at the pre-test result we chose students with average and high anxiety and divided them into the experimental and control group.

2) The Mindfulness training for experimental group

The Mindfulness training can be defined as exercises given to the experimental group by a Yoga instructor. The trainings were performed with 30 minutes duration per session, given in 8 sessions. The training lasted from 9 AM up to 9.30 AM in the multipurpose room. The students in the control group did not have any treatment; they were doing usual learning activities.

\section{3) Post-test}

After eighth session of the mindfulness training with the experiment group, then post-test was conducted for the control and experiment groups. The aim was to determine exam anxiety using the Exam Anxiety Scale, the same scale was used for the pre-test.

For the data analysis, t-test in pairs and independent $t$-test were used. The accuracy in this research is $95 \%$, thus it can be said that error tolerance level or accuracy coefficient in this research is $5 \%$ or 0.05 .

\section{Results}

\subsection{The result of independent t-test}

As for the performed independent t-test for the pre-test results of the experiment and control groups, the significant levels are 0.488 and 0.482 . The results are greater than the significant level of 0.05 , which means that Ho is accepted. So, it can be concluded that there are no differences for average anxiety between the experiment group pre-test and the control group pre-test (Figure 1).

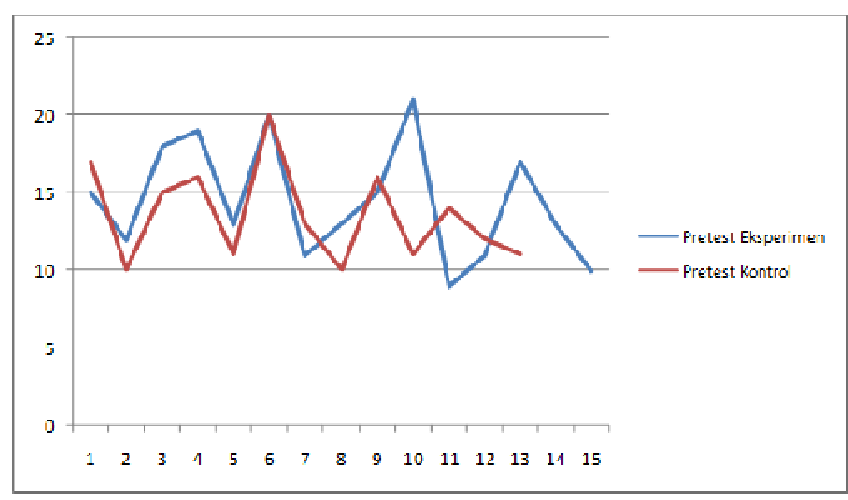

Figure 1.Pre-test for the experiment and control groups

The performed independent t-test for the post-test results of the experiment and control groups showed the significance levels of 0.011 and 0.014 , which is less than 0.05 . Thus, Ho is rejected, and it can be concluded that there is difference for average exam anxiety between the experiment group post-test and the control group post-test

(Figure 


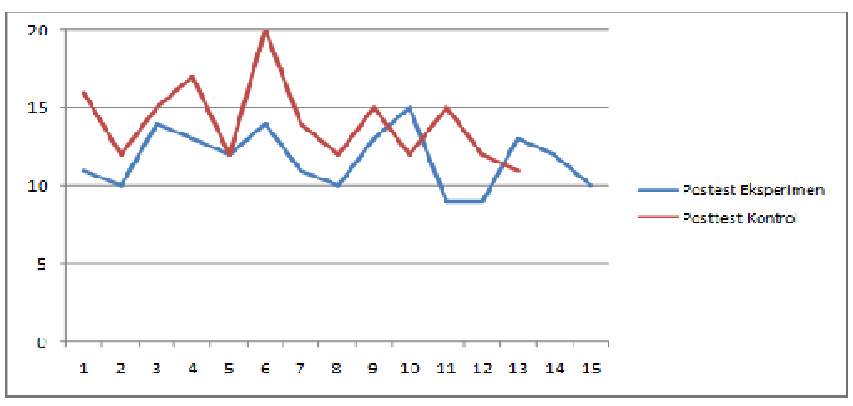

Figure 2. Post-test on the experiment and control groups

\subsection{The Result of T-test in Pairs}

The performed t-test in pairs for the experimental group showed the significance level of 0.000 , which is less than 0.05 . So, Ho is rejected, and it can be concluded that there is difference for average exam anxiety between the pre-test and post-test results obtained at the experimental group participated at the Mindfulness training.

The performed paired t-test for the control group showed the significance level of 0.068 , which is greater than the significance level of 0.05 . Then, Ho is accepted and it can be concluded that there is no difference for average exam anxiety between pre-test and post-test results obtained at the control group.

\subsection{Pre-test and Post-test of the Experimental} and Control Groups

\section{A. Pre-test and Post-test of the Experimental Group}

The level of exam anxiety at the experiment group decreased significantly after 8 ses- sions per 30 minutes of the Mindfulness trainings. The comparison of exam anxiety scores between the pre-test and the post-test can be seen in the graphic below (Figure 3) :

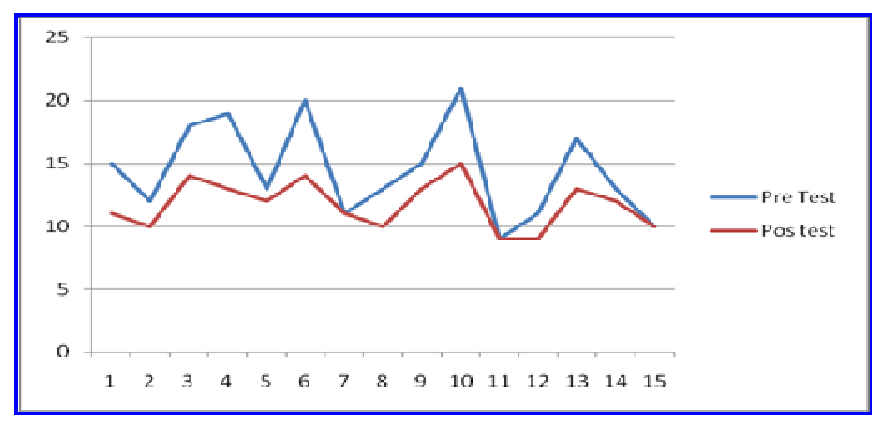

Figure 3. Pre-test and Post-test at the Experiment Group

\section{B. Pre-test - Post-test at the Control Group}

The level of exam anxiety in the control group, not participated in the Mindfulness trainings, did not become significantly lower. The comparison of anxiety score between the pre-test and the post-test can be seen in the figure below (Figure 4):

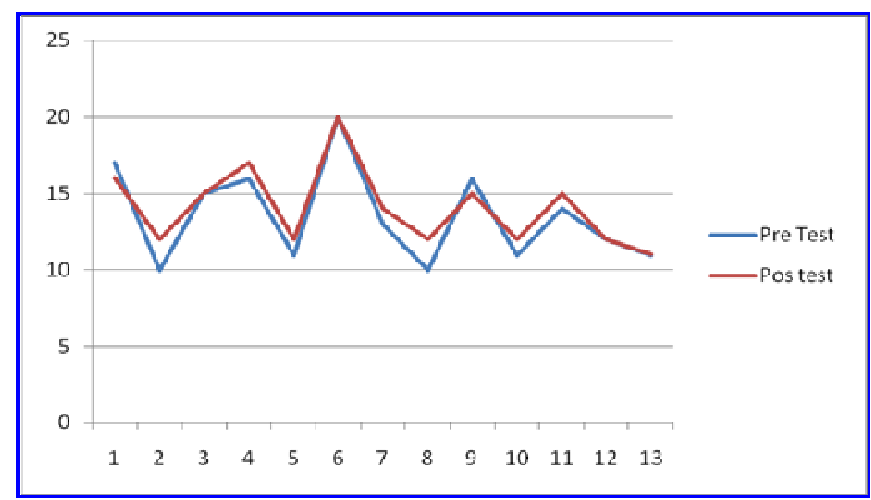

Figure 4. Pre-test and Post-test of the Control Group 
DOI (Issue): https://doi.org/10.31108/1.2019.5.11

\section{Discussion}

This study aim was to determine whether the proposed Mindfulness training can reduce exam anxiety. Exam anxiety is a problem that frequently occurres at school-age children (Ergene, 2011). It is one of the specific form of anxiety which marked with (1) cognitive symptoms, including fearful thought, fear of failure, fear of other's expectations and doubtful mind, (2) physical symptoms, such as sweating, rapid heartbeat, headaches, nausea, diarrhea, and (3) behavioral symptoms such as daydreaming, weak concentration, playing with stationary, and inability to sit comfortably while doing the test. Yi Tang and Westwood (as qtd. in Waring, 2014) claims that the anxiety degree experienced by children varies through mild to severe, but it is rare to find students who are free from anxiety in academic and school aspects. Students who expe- rience mild symptoms had better academic performance in comparison with those who experience the severe symptoms of exam anxiety (Nyroos, 2014).

The Mindfulness trainings in 8 sessions with 30 minutes duration for each session were used in our research. This training was done in 8 days in a row with the experimental group consisted of 15 children of the 4th-grade. While the control group, consisted of 13 children of the 5thgrade, followed the lessons as usual without any additional influence. The mindfulness training is composed in four types of exercises, namely (a) mindfulness smile, (b) breathing, (c) physical activities, and (d) sensory activities, with some ac-
Volume 5 Issue 112019

tivities at each training session that suitable for children.

The performed study showed that the Mindfulness training reduced exam anxiety in the experimental group better than that in the control group. It is proven by the result of paired t-test with the significance level of 0.000 , which is smaller than the significance standard of 0.05 . The independent t-test for the pre-test results shown by the experiment and control groups had the significance level of 0.488 and 0.482 , which is greater than the significance standard. So, there were no differences for average exam anxiety during pre-testing between the experimental and control groups. Exam anxiety in its early condition (before the Mindfulness training) of either the experiment group or the control group was the same in average. Significant anxiety reduction was achieved after the Mindfulness training. The independent t-test for the post-test results of both experiment and control group showed the significance levels of 0.011 and 0.014 , which is smaller than the significance standard of 0.05 . This result is similar to some previous studies that indicated Mindfulness training as one of the effective strategies to reduce exam anxiety (Napoli et al., 2005; Zelazo \& Lyons, 2012).

One of the factors causing psychological disturbances is individuals' mindset and irrational believes. These irrational believes lead people, having anxiety, to view at some event as something negative (Bridges \& Harnish, 2010). According to Gerwing et al., (2015) people who experience exam anxiety experience stronger fear to 
DOI (Issue): https://doi.org/10.31108/1.2019.5.11

receive bad examination results and failure. Some studies claim that worrying influence more strongly on exam failures than psychological pressure (Segool et al., 2014). When students feel worried, their attention is shifted to themselves rather than to the ongoing examination. This, indeed, make the students unable to show good performance due to their focus on the consequence of failure. Students show signs of worries verbally and their thoughts are focused on the bad expectations and pessimistic feelings before and/or during an exam which led to bad performance and failure (Soffer, 2008).

Anxious students tend to have the worrying focus that chronically pointed on futureoriented thinking without figuring out the present reality (Hooker \& Fodor, 2008). They always feel worried about "what will happen" in the future rather than focus on "what is happening" in the present. Their thoughts are filled with worries on things that not yet happen, such as the negative reactions of their parents and friends; the difficulty of a test, and bad scores. Because of such thoughts, students becomes pessimistic, desperate, without self- esteem but with low mood and low motivation, which affect the academic performance (Ergene, 2011; Huberty, 2009; Soffer, 2008; Talbot, 2016).

The Mindfulness training provides an alternative way to attract someone's attention to focused on the present moment and to break the mala- daptive anxiety chain (Hooker \& Fodor, 2008). The Mindfulness training changes students' per- spective from negative thoughts
Volume 5 Issue 112019

on something that not yet happen to the present. Students are trained to be fully aware on the present situation and condition instead of worrying about something that might happen (or not) in the future. Through the training, students will be able to focus on the present situation and condition and find the positive coping to prepare for exams. By focusing, students are trained to control their wandering, automatic mind, to get rid of depressive and fearful thoughts, to reduce reactive and impulsive attitudes and to have the ability to sharp mind and feeling into a more rational way (Weare, 2014). The Mindfulness training will train children to have internal and external experiences with the objective focus on the "present" rather than on the "past" or "future" time subjectively and reactively (Meiklejohn et al., 2012).

Students are invited to not give any judgment on negative thoughts related to the evaluative situation. Students often have thoughts that exam is a hard thing, even if it is not true, which will become obvious later. The Mindfulness training trains students to observe, attend, and accept every thought and body sensation that appeared 
without giving any judgment. By accepting the whole thought and body sensation, changes will happen (Hooker \& Fodor, 2008).

The basic Mindfulness training for children also teaches them the breathing techniques. The breathing techniques help children not to react under psychological pressure, for example, before exams. Students are trained to set up and watch on their breath if they feel worried about an exam. Deep and directed breathing can help calm the body and increase the concentration. In this case, the Mindfulness training help to enhance self-regulation and think before acting, hence Mindfulness can help students in managing their worries (Dobson, 2012).

Exam anxiety correlates negatively with students' well-being and reduce their academic performance (Steinmayr, et al., 2016). Mindfulness meditations, which are an integral element in the positive psychology, have the goal to enhance psychological well-being (Cebolla et al., 2017). Psychological well-being is defined as a combination of positive emotions and good feelings (Huppert \& Johnson, 2010). The reduction of exam anxiety symptoms will automatically create comfort emotions and feelings; thus, it enhances students' academic performance. Good academic performance determines the student's well-being (Quinn \& Duckworth, 2007). So, the Mindfulness training can contribute to students' psychological wellbeing (Kuyken et al., 2013).

The researcher realizes that this study have some limitations such as the internal validity test which was not implemented for the Mindfulness exercise module. The validation of the exercise module is only based on the theoretical concept since there is still no exercise module developed exactly for Indonesia children. The used of Mindfulness training program is also not systematically monitored yet. There is still no feedback either from the instructor or the targeted students. Another limitation is absence of qualitative analysis for each researched subject as for their anxiety before, during or after the training.

\section{Conclusion}

The Mindfulness training can be used as an alternative way to attract someone's attention to the present moment and to break the maladaptive anxiety chain. This approach is aimed to train students to observe, attend, and accept every appeared thought and body sensation without any judgment. With acceptance of all thoughts and body sensations, changes will happen. Based on the results that are explained above, this study shows that the Mindfulness training can reduce anxiety in the experimental group better than in the control group. It is proven by the paired t- test results with the obtained significance level of 0.000 , which is smaller than the significance standard if 0.05 . The independent t-test for the pre-test filled by the experiment and control groups has the significance levels of 0.488 and 0.482 , which bigger than the significance standard. 


\section{Suggestion}

For the further research, we propose to add demographic factors such as gender, social economic background and others in order to study exam anxiety characteristic for different population groups. Thus, the effectiveness of the Mindfulness training can be estimated more accurately. The replication on this study with different elementary school students should be done to increase the accuracy of experiment result. The mindfulness training instructor can be chosen from teachers who understand the stages of children's development; this will help correlate the research with children's psychological development at each stage. Follow up study of anxiety in some periods after the mindfulness training can be done in order to evaluate stability of students' exam anxiety reduction. Therefore, in the further research, a continued training program can be used to reduce exam anxiety not only for a short term but also for a long time.

\section{References :}

Albrecht, N. J., Albrecht, P. M., \& Cohen, M. (2012). Mindfully teaching in the classroom: A literature review. Australian Journal of Teacher Education, $37(12), \mathrm{n} 12$.

Bridges, K. R., \& Harnish, R. J. (2010). Role of irrational beliefs in depression and anxiety: a review. Health, 2(08), 862 .

Cebolla, A., Enrique, A., Alvear, D., Soler, J., \& Garcia-
Campayo, J. (2017). Contemplative Positive Psychology: Introducing Mindfulness Into Positive Psychology. Papeles Del Psicologo, 38(1), 12-18.

Dobson, C. (2012). Effects of academic anxiety on the performance of students with and without learning disablities and how students can cope with anxiety at school. Michigan. Northern Michigan University. Retrieved.

Ergene, T. (2011). The relationships among test anxiety study habits achievement motivation and academic performance among Turkish secondary school students. Egitim ve Bilim, 36(160), 320.

Gerwing, T. G., Rash, J. A., Allen Gerwing, A. M., Bramble, B., \& Landine, J. (2015). Perceptions and Incidence of Test Anxiety. Canadian Journal for the Scholarship of Teaching and Learning, 6(3), 3.

Hooker, K. E., \& Fodor, I. E. (2008). Teaching mindfulness to children. Gestalt Review, 12(1), 75-91.

Huberty, T. J. (2009). Test and performance anxiety. Principal Leadership, 10(1), 12-16.

Huppert, F. A., \& Johnson, D. M. (2010). A controlled trial of mindfulness training in schools: The importance of practice for an impact on well-being. The Journal of Positive Psychology, 5(4), 264-274.

Kuyken, W., Weare, K., Ukoumunne, O. C., Vicary, R., Motton, N., Burnett, R., ... Huppert, F. (2013). Effectiveness of the Mindfulness in Schools Programme: non-randomised controlled feasibility study. The British Journal of Psychiatry, 203(2), 126-131.

Meiklejohn, J., Phillips, C., Freedman, M. L., Griffin, M. L., Biegel, G., Roach, A., ... Soloway, G. (2012). Integrating mindfulness training into K-12 education: Fostering the resilience of teachers and students. Mindfulness, 3(4), 291-307.

Napoli, M., Krech, P. R., \& Holley, L. C. (2005). Mindfulness training for elementary school students: The attention academy. Journal of Applied School Psy- 
DOI (Issue): https://doi.org/10.31108/1.2019.5.11

chology, 21(1), 99-125.

Nijboer, J. M. (2007). Childhood Stress: Stressors, Coping, and Factors.

Nyroos, M. (2014). Childhood Test Anxiety-Booster, detainer, disability, disorder.

Quinn, P. D., \& Duckworth, A. L. (2007). Happiness and academic achievement: Evidence for reciprocal causality. The Annual Meeting of the American Psychological Society, 24(27.5), 2007.

Rempel, K. (2012). Mindfulness for children and youth: A review of the literature with an argument for schoolbased implementation. Canadian Journal of Counselling and Psychotherapy/Revue Canadienne de Counseling et de Psychothérapie, 46(3).

Schonert-Reichl, K. A., Oberle, E., Lawlor, M. S., Abbott, D., Thomson, K., Oberlander, T. F., \& Diamond, A. (2015). Enhancing cognitive and social-emotional development through a simple-to-administer mindfulness-based school program for elementary school children: A randomized controlled trial. Developmental Psychology, 51(1), 52.

Segool, N. K., Nathaniel, P., Mata, A. D., \& Gallant, J. (2014). Cognitive behavioral model of test anxiety in a high-stakes context: An exploratory study. School Mental Health, 6(1), 50-61.

Soffer, M. E. (2008). Elementary students' test anxiety in relation to the Florida comprehensive assessment test (FCAT).

Steinmayr, R., Crede, J., McElvany, N., \& Wirthwein, L. (2016). Subjective well-being, test anxiety, academic achievement: Testing for reciprocal effects. Frontiers in Psychology, 6, 1994.

Syamsu Yusuf, L. N. (2004). Psikologi perkembangan anak dan remaja. Bandung: PT Remaja Rosda Karya.

Talbot, L. (2016). Test anxiety: Prevalence, effects, and interventions for elementary school students. James Madison Undergraduate Research Journal (JMURJ),
Volume 5 Issue 112019

$3(1), 5$.

Waring, K. (2014). Social learning theory and child academic anxiety. University of Georgia.

Weare, K. (2014). Evidence for mindfulness: Impacts on the wellbeing and performance of school staff. Mindfulness in Schools Project, 1-23.

Wren, D. G., \& Benson, J. (2004). Measuring test anxiety in children: Scale development and internal construct validation. Anxiety, Stress \& Coping, 17(3), 227-240.

Zelazo, P. D., \& Lyons, K. E. (2012). The potential benefits of mindfulness training in early childhood: A developmental social cognitive neuroscience perspective. Child Development Perspectives, 6(2), 154-160.

\section{Дюжойс Картіка Сарі}

Центр розвитку дитини Пелангі Хати,

Дж.л. Жанглі Габенг Рая № 1, Семаранг, Центральна Ява (Індонезія)

\section{НАВЧАННЯ ШКОЛЯРІВ МОЛОДШИХ КЛАСІВ УСВІДОМЛЕНОСТІ ДЛЯ ЗНИЖЕННЯ РІВНЯ ТРИВОЖНОСТІ В ПЕРІОД ЗДАЧІ ІСПИТІВ}

\section{АНОТАЦІЯ}

Дана стаття присвячена розгляду проблеми тривожності у школярів молодшої школи, які досить часто стикаються 3 ситуаціями підвищеного рівню занепокоєння та тривожності в навчальному процесі. Одним 3 найбільш яскравих періодів підвищеного занепокоєння і зростання тривожності є екзаменаційний період, який розглядається в цій статті. Це дослідження фокусується на рівні тривожності, яку випробовують учнями четвертого і п’я- 
DOI (Issue): https://doi.org/10.31108/1.2019.5.11

того класів початкової школи. Тренінг щодо підвищення рівня усвідомленості, що проводиться в частині контрольної групи, був спрямований як на отримання результату, так і на визначення впливу усвідомленості на тривожність, що випробовується учнями четвертого і п'ятого класів початкової школи. Це дослідження показало, що тренування усвідомленості і уважності знижує рівень тривоги на іспиті в експериментальній групі в порівнянні 3 частиною контрольної групи, де такий тренінг не проводився. Це, зокрема, видно по парним результатами t-тесту 3 рівнем значущості 0,000, що менше, ніж стандарт значущості 0,05, який спостерігається в групі, тренінг в якої не було проведено. Незалежний критерій Стьюдента для результатів попереднього тесту, отриманих в експериментальній і контрольній групах, показав значущі рівні 0,488 i 0,482, що перевищує стандарт значущості. Отже, тренування усвідомленості і уважності може використовуватися в якості альтернативного способу, при якому чиюсь увагу залучається до справжнього моменту, щоб розірвати ланцюжок неадаптивної тривоги.

Ключові слова: тривога, тривожність, тривога дітей, тиск на іспиті, тренування уважності, усвідомлення, усвідомленість.
Volume 5 Issue 112019

\section{Дожойс Картика Сари}

Центр развития ребенка Пеланги Хати, Дж.л. Жангли Габенг Рая № 1, Семаранг, Центральная Ява (Индонезия)

\section{ОБУЧЕНИЕ ОСОЗНАННОСТИ ШКОЛЬНИКОВ МЛАДШИХ КЛАССОВ ДЛЯ СНИЖЕНИЯ УРОВНЯ ТРЕВОЖНОСТИ ПРИ СДАЧЕ ЭКЗАМЕНОВ}

\section{АННОТАЦИЯ}

Данная статья посвящена рассмотрению проблемы тревожности у школьников младшей школы, которые довольно часто сталкиваются с ситуациями повышающими уровень беспокойства в процессе обучения. Одним из наиболее ярких периодов повышенного беспокойства и роста тревожности является экзаменационный период, который рассматривается в этой статье. Это исследование фокусируется на уровне тревожности, испытываемой учениками четвертого и пятого классов начальной школы. Тренинг по повышению уровня осознанности, проводимый в части контрольной группы, был направлен как на получение результата, так и на определение влияния осознанности на тревожность, испытываемую учениками четвертого и пятого классов начальной школы. Это исследование показало, что тренировка осознанности и внимательности понижает уровень тревоги на экзамене в экспериментальной группе в сравнении с частью контрольной группы, где такой тренинг не проводился. Это, в частности, видно по парным результатам t-теста с уров- 
нем значимости 0,000 , что меньше, чем стандарт значимости 0,05 , который наблюдается в группе, тренинг в которой не провдился. Независимый критерий Стьюдента для результатов предварительного теста, полученных в экспериментальной и контрольной группах, показал значимые уровни 0,488 и 0,482 , что превышает стандарт значимости. Следовательно, тренировка осознанности и внимательности может использоваться в качестве альтернативного способа, при котором чье-то внимание привлекается к настоящему моменту, чтобы разорвать цепочку неадаптивной тревоги.

Ключевые слова: тревога, тревожность, тревожность детей, давление на экзамене, внимательность, осознанность. 